\title{
Feeding Ecology of Pterois volitans on the Coral Reefs of Northern Veracruz, Mexico
}

\author{
Carlos González-Gándara*, Pastor Alberto Escarcega-Quiroga and Seth Donovan Flores-Serrano \\ Facultad de Ciencias Biológicas y Agropecuarias, Universidad Veracruzana, Mexico
}

Submission: July 16, 2020; Published: August 10, 2020

Corresponding author: Carlos González-Gándara, Laboratorio de Arrecifes Coralinos, Facultad de Ciencias Biológicas y Agropecuarias, Universidad Veracruzana, Tuxpan, Veracruz, Mexico Email: cggandara@hotmail.com

\begin{abstract}
Knowledge of the lionfish's diet composition on a regional scale is essential to assess the impact that an increase in population density can have on native populations. This paper documents for the first time the diet of Pterois volitans in coral reefs of Veracruz (southwestern Gulf of Mexico). For this, 29 organisms from three reefs in northern Veracruz were analyzed. $95.2 \%$ of the stomach contents of lionfish were represented by fish and $4.8 \%$ by crustaceans. Among the most frequent species in the diet of $P$. volitans were: Halichoeres burekae, Chromis scotti, Malacoctenus triangulatus and Tigrigobius redimiculus. The results reveal that the increase in the population density of the lionfish in the region may represent a threat to the regional endemic species.
\end{abstract}

Kewords: Lionfish; Diet composition; Coral reefs; Gulf of Mexico

Acknowledgement: This research is part of the "Red para el Análisis y Síntesis de la Zona Costera Veracruzana, Golfo de México" financed by the Ministry of Public Education.

\section{Introduction}

Knowledge of the feeding ecology of the lionfish in the reefs of Veracruz is fundamental to assess the impact that this species can have on native fish populations and particularly on regional endemics [1], given that Pterois volitans is a generalist and voracious predator [2,3]. Although the lionfish was recorded since 2011 in the reef formations of Veracruz [4], knowledge of its biology is limited. Recently, the lionfish diet was published based on catches made in the soft bottom areas near the Veracruz Reef System [5]. This research concludes that the diet of $P$. volitans includes fish linked to the substrate, but there is no certainty that the recorded components are associated with reef structures. In the present investigation, an evaluation of the diet of lionfish from organisms captured in coral reefs of northern Veracruz is presented for the first time, in order to understand the lionfish diet in the region and assess its impact on reef fish populations.

\section{Materials and Methods}

From 2015 to 2019, 71 lionfish were collected using harpoons and SCUBA diving equipment in the reefs of northern Veracruz:

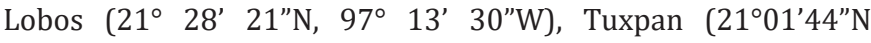
$\left.97^{\circ} 11^{\prime} 42^{\prime \prime} \mathrm{W}\right)$ and Blake (20 $\left.45^{\prime} 45^{\prime \prime} \mathrm{N}, 96^{\circ} 59^{\prime} 30^{\prime \prime} \mathrm{W}\right)$. Of the fish captured (mainly on the leeward slope), only 29 presented stomach contents. Each of the organisms captured was measured with an ichthyometer to nearest $0.01 \mathrm{~cm}$ and placed in a container with ice. Stomach contents were extracted from each specimen and separated into food items for identification at the lowest possible taxonomic level, using the keys of McEachran and Fechhelm [6,7] as well as the publications of Taylor and Akins, Weaver and Rocha $[8,9]$ for fish and Abele and Kim [10] for crustaceans. Subsequently, the relative abundance of each taxonomic group was estimated, considering the total number of individuals contained in the stomach.

\section{Results and Discussion}

The organisms analyzed presented between 11.6 and $37.0 \mathrm{~cm}$ of total length $(22.9 \pm 1.4$ Mean \pm SE). Most of them were captured between 10 and $20 \mathrm{~m}$ in depth. The results indicate that the diet of P. volitans in the reefs of northern Veracruz included: crustaceans (4.8\%) and fish (95.2\%). These values coincide with the observations of Aguilar-Medrano and Vega-Cendejas [5], but not with the referred components, because it seems that the reported genera and species inhabit silty or sandy substrates. Crustaceans were represented by the families: Mysidae and Squillidae, while fish were represented by the families: Blenniidae, Gobiidae, 
Labridae, Labrisomidae, Pomacentridae and Tripterygiidae, which have already been recorded by other authors in reefs of the Caribbean and Gulf of Mexico. The most frequent species in the diet of $P$. volitans, in order of relative abundance, were: Halichoeres burekae (24\%), Chromis scotti (11\%), Malacoctenus triangulatus (7\%) and Tigrigobius redimiculus (7\%). Other species identified as part of the stomach content were: Enneanectes boehlkei, Ophioblennius maclurei, Stegastes planifrons and Thalassoma bifasciatum.

All species consumed by lionfish in the reefs of northern Veracruz live on the substrate (e.g. M. triangulatus) or on top of colonies or coral structures (e.g. C. scotti). Among the species consumed by the lionfish in the region are H. burekae (endemic to the Gulf of Mexico) and T. redimiculus (endemic to Veracruz), which are added to the list of species consumed by $P$. volitans. This confirms the suspicions of Rocha et al [1] and GonzálezGándara [11] about the threat posed by lionfish to these two species. In some cases, $100 \%$ of the stomach contents of the lionfish corresponded to $H$. burekae, which is explained by both the distribution of this species on the reef and its abundance, as it is one of the most abundant on the reefs of the southwestern Gulf of Mexico [12,13]. The information in this paper reveals that the increase in lionfish density in the reefs of northern Veracruz may represent a threat to the regional endemic species. Therefore, assessments of lionfish abundance are necessary to generate control measures and mitigate the effect on native species. If control measures are not established, endemic species as well as small substrate-linked fishes (Tripterygiidae, Labrisomidae, Gobiidae) may decrease their population density.

\section{References}

1. Rocha LA, Rocha CR, Baldwin CC, Weigt LA, McField M (2015) Invasive lionfish preying on critically endangered reef fish. Coral Reefs 34: 803806.

2. Morris Jr J, Akins JL (2009) Feeding ecology of invasive lionfish (Pterois volitans) in the Bahamian archipelago. Environmental Biology of Fishes 86: 389-398.
3. Peake J, Bogdanoff AK, Layman CA, Castillo B, Reale-Munroe K, et al. (2018) Feeding ecology of invasive lionfish (Pterois volitans and Pterois miles) in the temperate and tropical western Atlantic. Biological Invasions 20: 2567-2597.

4. Santander-Monsalvo J, López-Huerta I, Aguilar-Perera A, Tuz-Sulub A (2012) First record of the red lionfish (Pterois volitans [Linnaeus, 1758]) off the coast of Veracruz, México. BioInvasions Records 1(2): 121-124.

5. Aguilar-Medrano R, Vega-Cendejas ME (2020) Size, weight, and diet of the invasive lionfish Pterois volitans (Linnaeus, 1758) on the southern coast of Veracruz, Gulf of Mexico. Ciencias Marinas 46(1): 57-64.

6. McEachran JD, Fechhelm, JD (1998) Fishes of the Gulf of Mexico. In: Myxiniformes to Gasterosteiformes, University of Texas Press, Texas, US, P. 1112.

7. McEachran JD, Fechhelm JD (2005) Fishes of the Gulf of Mexico. In: Scorpaeniformes to Tetraodontiformes, University of Texas Press, Texas, P. 1004

8. Taylor MS, Akins L (2007) Two new species of Elacatinus (Teleostei: Gobiidae) from the Mexican coast of the Gulf of Mexico. Zootaxa 1425(1): 45-51.

9. Weaver DC, Rocha LA (2007) A new species of Halichoeres (Teleostei: Labridae) from the western Gulf of Mexico. Copeia 4: 798-807.

10. Abele LG, Kim W (1986) An illustrated guide to the marine decapod crustaceans of Florida. Department of Environmental Regulation Technical Series, Florida 8: 1-760.

11. González-Gándara C (2020a) What do we know about Pterois volitans in the Reefs of Veracruz, Mexico? Oceanography and Fisheries Open access Journal 12(1): 555828.

12. Pérez-España H, Bello-Pineda J, Ávila-Santiago P, Berumen-Solorzano P, Melo-Merino S, et al. (2015) Monitoreo del Parque Nacional Sistema Arrecifal Veracruzano: Segunda Etapa. Universidad Veracruzana, Instituto de Ciencias Marinas y Pesquerías. Informe final SNIBCONABIO, proyecto GM004, México.

13. González-Gándara C (2020b) La comunidad de peces del arrecife Palo Seco, Veracruz, golfo de México y su relación con los grupos morfofuncionales. CienciaUAT 14(2): 34-50.
Your next submission with Juniper Publishers will reach you the below assets

- Quality Editorial service

- Swift Peer Review

- Reprints availability

- E-prints Service

- Manuscript Podcast for convenient understanding

- Global attainment for your research

- Manuscript accessibility in different formats ( Pdf, E-pub, Full Text, Audio)

- Unceasing customer service

Track the below URL for one-step submission https://juniperpublishers.com/online-submission.php 